\title{
Relevansi Peradilan Pidana Internasional Dalam Upaya Penegakan HAM Telaah Kritis atas Rome Statute of the International Criminal Court
}

\author{
Oleh : \\ SALMAN LUTHAN
}

\begin{abstract}
Idea of Human Right as universal ideology has been agreed by the nations and poured in Universal Declaration of Human Rights released by United Nations on 1 December 1948. This declaration aims to protect the rights of human being and pushs the creation of freedom of human being without colour line, gender difference, Ianguage difference, and also religion difference. The protection of Human Rights regulated also on Rome Statute on the International Criminal Court becoming base to forming of International Criminal Court (ICC). In this time ICC faces some constraint influencing its effectivity in doing the role. But, the constraint do not eliminate its role in the effort of straightening of Human Rights
\end{abstract}

